\title{
Non-target effects of a glyphosate-based herbicide on Common Toad larvae (Bufo bufo, Amphibia) and associated algae are altered by temperature
}

\author{
Fabian Baier ${ }^{1}$, Edith Gruber ${ }^{1}$, Thomas Hein ${ }^{2,3}$, Elisabeth Bondar-Kunze ${ }^{2,3}$, Marina Ivanković ${ }^{2}$, Axel \\ Mentler $^{4}$, Carsten A Brühl ${ }^{5}$, Bernhard Spangl ${ }^{6}$, Johann G Zaller ${ }^{\text {Corresp. } 1}$ \\ 1 Institute of Zoology, University of Natural Resources and Life Sciences Vienna (BOKU), Vienna, Austria \\ 3 WasserCluster Lunz - Biologische Station GmbH, Lunz am See, Austria \\ 4 Institute of Soil Research, University of Natural Resources and Life Sciences Vienna (BOKU), Vienna, Austria \\ 5 Institute for Environmental Sciences, Universität Koblenz-Landau, Landau, Germany \\ 6 Institute of Applied Statistics and Computing, University of Natural Resources and Life Sciences Vienna (BOKU), Vienna, Austria \\ Corresponding Author: Johann G Zaller \\ Email address: johann.zaller@boku.ac.at
}

Background. Glyphosate-based herbicides are the most widely used pesticides in agriculture, horticulture, municipalities and private gardens that can potentially contaminate nearby water bodies inhabited by amphibians and algae. Moreover, the development and diversity of these aquatic organisms could also be affected by human-induced climate change that might lead to more periods with extreme temperatures. However, to what extent non-target effects of these herbicides on amphibians or algae are altered by varying temperature is not well known.

Methods. We studied effects of five concentrations of the glyphosate-based herbicide formulation Roundup PowerFlex $\left(0,1.5,3,4 \mathrm{mg}\right.$ acid equivalent glyphosate $\mathrm{L}^{-1}$ as a one time addition and a pulse treatment of totally $4 \mathrm{mg}$ a.e. glyphosate $\mathrm{L}^{-1}$ ) on larval development of Common toads (Bufo bufo, L.; Amphibia: Anura) and associated algae communities under two temperature regimes $\left(15^{\circ} \mathrm{C}\right.$ vs. $\left.20^{\circ} \mathrm{C}\right)$.

Results. Herbicide contamination reduced tail growth (-8\%), induced the occurrence of tail deformations (i.e. lacerated or crooked tails) and reduced algae diversity (-6\%). Higher water temperature increased tadpole growth (tail and body length $+66 \%$, length-to-width ratio $+4 \%$ ) and decreased algae diversity ($21 \%$ ). No clear relation between herbicide concentrations and tadpole growth or algae density or diversity was observed. Interactive effects of herbicides and temperature affected growth parameters, tail deformation and tadpole mortality indicating that the herbicide effects are temperature-dependent. Remarkably, herbicide-temperature interactions resulted in deformed tails in $76 \%$ of all herbicide treated tadpoles at $15^{\circ} \mathrm{C}$ whereas no tail deformations were observed for the herbicide-free control at $15^{\circ} \mathrm{C}$ or any tadpole at $20^{\circ} \mathrm{C}$; herbicide-induced mortality was higher at $15^{\circ} \mathrm{C}$ but lower at $20^{\circ} \mathrm{C}$.

Discussion. These herbicide- and temperature-induced changes may have decided effects on ecological interactions in freshwater ecosystems. Although no clear dose-response effect was seen, the presence of glyphosate was decisive for an effect, suggesting that the lowest observed effect concentration (LOEC) in our study was $1.5 \mathrm{mg}$ a.e. glyphosate $\mathrm{L}^{-1}$ water. Overall, our findings also question the relevance of pesticide risk assessments conducted at standard temperatures. 
1 Non-target effects of a glyphosate-based herbicide on Common Toad larvae (Bufo

2 bufo, Amphibia) and associated algae are altered by temperature

3

4 Fabian Baier $^{1}$, Edith Gruber ${ }^{1}$, Thomas Hein ${ }^{2,3}$, Elisabeth Bondar-Kunze ${ }^{2,3}$, Marina Ivankovic ${ }^{3}$,

5 Axel Mentler ${ }^{4}$, Carsten A. Brühl ${ }^{5}$, Bernhard Spangl ${ }^{6}$ \& Johann G. Zaller ${ }^{*}$

6

7

8 Author affiliations

$9 \quad{ }^{1}$ Institute of Zoology, University of Natural Resources and Life Sciences Vienna (BOKU), Austria 10

${ }^{2}$ Institute of Hydrobiology and Aquatic Ecosystem Management, University of Natural Resources and Life Sciences (BOKU), Vienna, Austria

13

${ }^{3}$ WasserCluster Lunz - Biologische Station GmbH, Lunz am See, Austria 15

${ }^{4}$ Institute of Soil Research, University of Natural Resources and Life Sciences (BOKU), Vienna, Austria 17 
24 Abstract

25 Background. Glyphosate-based herbicides are the most widely used pesticides in agriculture, horticulture, municipalities and private gardens that can potentially contaminate nearby water bodies inhabited by amphibians and algae. Moreover, the development and diversity of these aquatic organisms could also be affected by human-induced climate change that might lead to more periods with extreme temperatures. However, to what extent non-target effects of these herbicides on amphibians or algae are altered by varying temperature is not well known.

Methods. We studied effects of five concentrations of the glyphosate-based herbicide formulation Roundup PowerFlex $\left(0,1.5,3,4 \mathrm{mg}\right.$ acid equivalent glyphosate $\mathrm{L}^{-1}$ as a one time addition and a pulse treatment of totally $4 \mathrm{mg}$ a.e. glyphosate $\mathrm{L}^{-1}$ ) on larval development of Common toads (Bufo bufo, L.; Amphibia: Anura) and associated algae communities under two temperature regimes $\left(15^{\circ} \mathrm{C}\right.$ vs. $\left.20^{\circ} \mathrm{C}\right)$.

Results. Herbicide contamination reduced tail growth (-8\%), induced the occurrence of tail deformations (i.e. lacerated or crooked tails) and reduced algae diversity (-6\%). Higher water temperature increased tadpole growth (tail and body length $+66 \%$, length-to-width ratio $+4 \%$ ) and decreased algae diversity (-21\%). No clear relation between herbicide concentrations and tadpole growth or algae density or diversity was observed. Interactive effects of herbicides and temperature affected growth parameters, tail deformation and tadpole mortality indicating that the herbicide effects are temperature-dependent. Remarkably, herbicide-temperature interactions

43 resulted in deformed tails in $76 \%$ of all herbicide treated tadpoles at $15^{\circ} \mathrm{C}$ whereas no tail

44 deformations were observed for the herbicide-free control at $15^{\circ} \mathrm{C}$ or any tadpole at $20^{\circ} \mathrm{C}$;

45 herbicide-induced mortality was higher at $15^{\circ} \mathrm{C}$ but lower at $20^{\circ} \mathrm{C}$. 
46 Discussion. These herbicide- and temperature-induced changes may have decided effects on

47 ecological interactions in freshwater ecosystems. Although no clear dose-response effect was

48 seen, the presence of glyphosate was decisive for an effect, suggesting that the lowest observed

49 effect concentration (LOEC) in our study was $1.5 \mathrm{mg}$ a.e. glyphosate $\mathrm{L}^{-1}$ water. Overall, our

50 findings also question the relevance of pesticide risk assessments conducted at standard

51 temperatures. 


\section{Introduction}

53 With almost a third of their species threatened, amphibians are the most vulnerable vertebrate 54 group on earth (IUCN 2004). Amphibian declines and extinctions are caused by multiple factors

55 and their interaction: alien species, over-exploitation and land use change, global change, 56 increased use of pesticides and other toxic chemicals and infectious diseases (Aldrich et al. 2016;

57 Blaustein et al. 2011; Brühl et al. 2013; Collins \& Storfer 2003). In their natural habitats,

58 especially anuran amphibians are always associated with algae communities that constitute an important source of nutrition during larval development, however, algae are likewise affected by

60 similar environmental factors as amphibians (Whitehead et al. 2009; Wilson et al. 2003). The

61 current study examined the effects of a glyphosate-based herbicide on growth and development

62 of larvae of Common toads (Bufo bufo L.) and on the composition of the associated algal

63 communities. Additionally, as climate change scenarios predict more frequent extreme

64 temperature events (IPCC 2013), we also assessed whether different water temperatures alter

65 potential herbicide effects. Moreover, toad spawning ponds can vary considerably in their depths

66 and in their water temperature. Globally, Common toads are mainly distributed in Europe living

67 in habitats from lowland to mountain areas up to $2500 \mathrm{~m}$ a.s.1. (Arnold \& Ovenden 2002;

68 Recuero et al. 2012). Since Common toads frequently spawn in ponds located near agriculturally

69 used areas or because they need to cross these landscapes during their seasonal migrations from

70 the spawning ponds to woody overwintering sites, they are frequently exposed to pesticides

71 (Berger et al. 2013; Lenhardt et al. 2015). Common toads were selected as a study organism also

72 for ethical reasons because they are among the least threatened of the generally endangered

73 animal class of Amphibia. 

agriculture, horticulture, forestry, vineyards, municipalities and private gardens. Generally, glyphosates' mode of action inhibits an enzyme only known to plants and some microorganisms; therefore, and due to the half-life of 7-14 days in water it is considered only slightly toxic to amphibians (Franz et al. 1997; Giesy et al. 2000). Most glyphosate-based herbicides are not meant to be used in or close to aquatic environments, however, contamination of water bodies through drift, surface runoff and direct overspray has been reported (Battaglin et al. 2009; Berger et al. 2013; Peruzzo et al. 2008). Nevertheless, several studies report detrimental effects of glyphosate-based herbicide formulations to amphibians during their aquatic and terrestrial life stages (Baylis 2000; Brühl et al. 2011; Duke \& Powles 2008; Fryday \& Thompson 2012; Relyea 2011; Tsui \& Chu 2003). Glyphosate-based herbicides tested in concentrations ranging between $0.021 \mathrm{mg}$ acid equivalent (a.e.) $\mathrm{L}^{-1}$ to $6.0 \mathrm{mg}$ a.e. $\mathrm{L}^{-1}$ affected growth and development of North American larval anurans (Edge et al. 2014; Lanctôt et al. 2014; Navarro-Martín et al. 2014; Relyea 2004), showed other sub-lethal morphological and behavioral effects (Cauble \& Wagner 2005; Mann \& Bidwell 1999; Moore et al. 2015; Muñoz et al. 2014) and even lead to acute mortality when exposed to high doses (Fuentes et al. 2011; Moore et al. 2012; Relyea 2005b; Williams \& Semlitsch 2010). However, concerning effects of glyphosate-based herbicides on native European amphibian species only very little is known (Wagner \& Lötters 2013). Moreover, it has been shown that herbicide formulations, i.e. the products that are actually used in the field, are more detrimental to tadpoles and other aquatic organisms than the active ingredient glyphosate itself (Folmar et al. 1979; Howe et al. 2004; Relyea 2005b). However, unfortunately these adjuvants are usually not declared and considered company secrets (Mullin et al. 2016; Wagner et al. 2013). Besides amphibians, several studies also show that freshwater 
97 microalgae are particularly vulnerable to glyphosate-based herbicides because of their

98 physiological and biochemical similarity with terrestrial plants (Annett et al. 2014; Tsui \& Chu

99 2003) mainly by initiating oxidative stress in algae (Annett et al. 2014).

100 Temperature has long been known to play an important role in the physiology and

101 ecology of tadpoles (Katzenberger et al. 2014; Ultsch et al. 1999) and algae (Butterwick et al.

102 2005; Schabhüttl et al. 2013). Although climate warming is not considered to be directly lethal to

103 amphibians, increasing water temperatures in amphibian breeding ponds may accelerate larval

104 development and hence reduce the duration of herbicide exposure for these species (Li et al.

105 2013; Rohr \& Palmer 2013). Potential interactions between herbicides and temperature are of

106 particular interest as human-induced climate change can increase mean temperatures and will

107 most likely also lead to weather events with more extreme temperatures (IPCC 2013). On the

108 other hand, pesticide use is also expected to rise with rising temperatures because certain pests

109 and diseases are expected to benefit from climate change (Kattwinkel et al. 2011). Interactions of

110 pesticide and global warming effects have been predicted and outlined as a major point of

111 concern for wildlife (Köhler \& Triebskorn 2013; Rohr \& Palmer 2013). Only very few studies

112 investigated combined effects of herbicides and temperature on amphibians (Baier et al. 2016;

113 Rohr et al. 2011). These studies show that increasing temperatures generally do not enhance the

114 toxicity of the herbicide, but rather temperature ameliorates the adverse effects of the herbicide

115 by accelerating development and reducing the duration of herbicide exposure (Baier et al. 2016;

116 Rohr et al. 2011).

117 Thus, the objectives of the current study were to assess whether (i) herbicide

118 concentrations affect the development of Common toad larvae and associated algae communities

119 and (ii) temperature alters potential herbicide effects. To investigate these objectives we 
120 conducted a climate chamber experiment using a full factorial design with five herbicide

121 concentrations at two temperature levels over 24 days. We hypothesized that a higher

122 temperature will accelerate the growth and development of tadpoles, hence reducing the duration

123 of their exposure to the herbicide. When higher temperature reduces exposure to the herbicide

124 more than it enhances detrimental effects of the herbicide, then its net effect could be beneficial.

125 Regarding herbicide effects we also hypothesized that increasing temperatures would increase

126 detrimental effects of the herbicide with increasing concentrations because multiple stressors

127 might decrease resources of amphibians for detoxification and/or temperature regulation (Noyes

128 et al. 2009; Rohr et al. 2003).

\section{Material and Methods}

\section{Experimental Setup}

The study was conducted between April 14 and May 9, 2015 in a laboratory at the University of Natural Resources and Life Sciences Vienna (BOKU), Austria. This study was carried out in strict accordance with the recommendations in the Austrian animal experimentation law (Tierversuchsgesetz 2012, BGB1. I Nr. 114/2012) with a permission from the Austrian Federal Ministry of Science, Research and Economy (permit number BMWFW-66.016/0002WF/V/3b/2015). Anesthetic MS222 (Triacin, Sandoz, Switzerland) was used when necessary to ameliorate animal suffering. The experiment was carried out using a full-factorial design, with herbicide concentration ( 5 levels) and temperature (2 levels) as factors. Two climate chambers

141 set at different temperatures $\left(15^{\circ} \mathrm{C}\right.$ and $\left.20^{\circ} \mathrm{C}\right)$ with a 12 hours light/dark-cycle were used to set

142 up the two temperature conditions. Light intensity of both climate chambers was measured using 
143 a Lux Meter (Voltcraft LX-1108 Lux-Meter; Conrad electronics, Hirschau, Germany) resulting

144 in $5575 \pm 106$ lux (mean \pm SD) in both chambers. We established the following herbicide

145 concentrations: $0,1.5,3,4 \mathrm{mg}$ a.e. $\mathrm{L}^{-1}$ (acid equivalent; which equals $0,3.13,6.25,8.33 \mu 1 \mathrm{~L}^{-1}$ of

146 the Roundup PowerFlex ${ }^{\circledR}$ formulation) from the start and $4 \mathrm{mg}$ a.e. $\mathrm{L}^{-1}$ applied as a pulse

147 treatment starting initially with $1.5 \mathrm{mg}$ a.e. $\mathrm{L}^{-1}$ and adding another $1.5 \mathrm{mg}$ a.e. $\mathrm{L}^{-1}$ on day 5 and 1

$148 \mathrm{mg}$ a.e. $\mathrm{L}^{-1}\left(2.08 \mu \mathrm{L}^{-1}\right)$ on day 11 after starting the experiment, respectively. In the field,

149 glyphosate concentrations in amphibian breeding ponds are generally highly variable depending

150 on potential pesticide drift or input through leaching by water or soil erosion. Worst-case

151 expected environmental concentration of $7.6 \mathrm{mg}$ a.e. glyphosate $\mathrm{L}^{-1}$ have been calculated

152 (Wagner et al. 2013), however during most of the year concentrations in spawning ponds are

153 likely to be lower (Peruzzo et al. 2008; Struger et al. 2008; Trumbo 2005). Five 25-L plastic

154 canisters were used to prepare herbicide solutions. First each canister was filled with $22 \mathrm{~L}$ of coal

155 filtered tap water, then the glyphosate-based herbicide Roundup PowerFlex (containing: $588 \mathrm{~g} \mathrm{~L} \mathrm{~L}^{-}$

$156{ }^{1}$ potassium salt of glyphosate, which equals $480 \mathrm{~g} \mathrm{~L}^{-1}$ glyphosate acid; Monsanto Europe

157 S.A./N.V., Belgium) was added in the desired concentrations using a micro-pipette. This

158 Roundup formulation is available in Europe since 2014 and admitted for usage in agriculture,

159 horticulture, forestry, vineyards, municipalities and private gardens until 2022 (AGES 2015).

160 Afterwards the solutions were mixed thoroughly by shaking and turning the canisters upside

161 down. Four liters of pure coal-filtered water (in case of the control) or the mixtures were then

162 filled into each experimental unit, i.e. polypropylene plastic tubs (volume: 5-L, length: $28 \mathrm{~cm}$, 163 width: $19 \mathrm{~cm}$, height: $14 \mathrm{~cm}$ ), accounting for 5 replicates per treatment. Each climate chamber 164 contained 25 tubs, making up a total of 50 tubs for the two temperature treatments. 

was hand-collected on 14 April 2015 from a pond in Neuwaldegg, Vienna (48¹4'26.31’N; $16^{\circ} 16^{\prime} 34.945$ 'E; altitude $290 \mathrm{~m}$ a.s.1.). Toad eggs were sampled with permission of the pond 168 owner (Vienna Municipal Department 49 - Forestry, permit number MA49-808754/2014/3) and the respective authority for nature conservation (Vienna Municipal Department 22 -

Environmental Protection, permit number MA22-1629490/2014). Five randomly chosen eggs of

171 the whole spawn were added into each experimental tub, accounting for a total of 250 eggs used

172 for this experiment.

\section{Measurements and Analyses}

Larval development was determined according to Gosner (Gosner 1960) using a binocular microscope (Nikon SMZ 745; Nikon, Tokyo, Japan). Conforming to this scheme the development of anurans is assigned to 46 stages (Gosner stage, Gs), from undivided eggs (Gs 1) to completely metamorphosed individuals (Gs 46). At the start of our experiment all tadpoles were in Gs 8. As additional morphological parameters we measured body length, body width and tail length from photographs taken of tadpoles from all treatments at May 8, when the maturity of larval amphibians reached Gs 30 and Gs 35 at $15^{\circ} \mathrm{C}$ and $20^{\circ} \mathrm{C}$, respectively. Measurements on photographs were conducted using the free image analysis software ImageJ (version $1.48 \mathrm{v}$, Wayne Rasband, National Institute of Health, USA, http://imagej.nih.gov/ij). Body condition was calculated as body length-to-width ratio. Tail deformations (Bantle et al. 1998; Cooke 1981) were assessed when taking the tadpoles out into Petri dishes for morphological measurements at the end of the experiment. A clear distinction could be made between undeformed (Figure 1A), lacerated (Figure 1B) or curved tails (Figure 1C); only curved tails were considered deformed (Cooke 1981) as lacerated tails could also originate from injuries by intraspecific competition. 

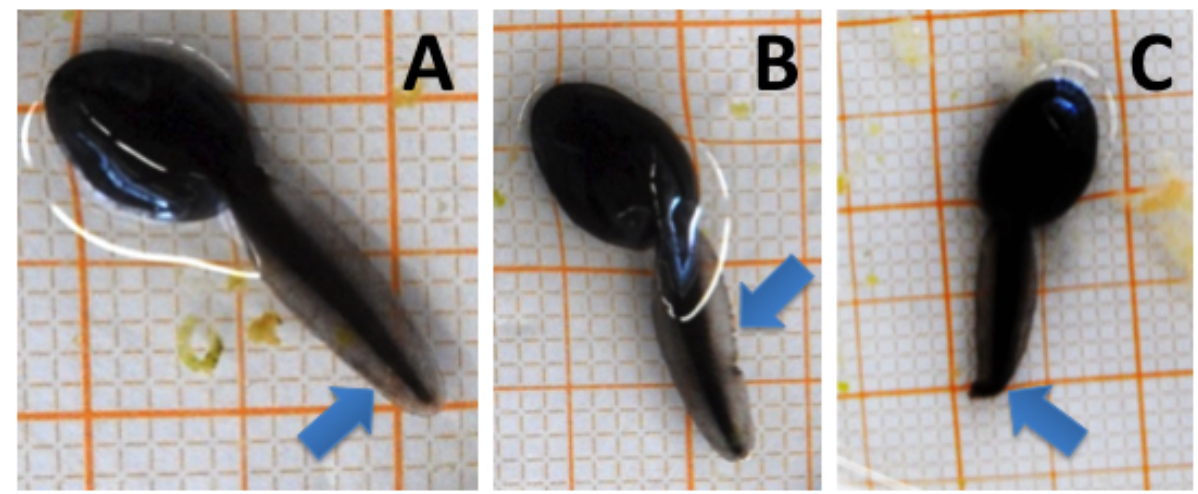

190

Figure 1: Tadpoles observed in the current experiment with undeformed (A), lacerated (B) and curved tail tips (C). Only curved tail tips were considered deformed and included in the analyses.

same amounts of ground fish food (Tetramin) after reaching Gs 22 . When most of the $20^{\circ} \mathrm{C}$ treated tadpoles reached Gs 35 (indentations 1-2 of the hind limbs develop at this stage) the experiment was terminated. Water samples of all tubs (also the $15^{\circ} \mathrm{C}$ ones) were taken after thoroughly mixing with a glass stirring rod using a $100 \mathrm{ml}$ plastic beaker; samples were preserved by adding 5 drops of Lugol iodine solution.

In these water samples algae species composition was examined. Algae were introduced into the experimental units via the tadpole eggs; as eggs were randomly assigned to the treatments we considered this as a similar initial situation for all treatments. For algae species determination, the phytoplankton samples were gently mixed by inverting the sample bottle. Initially a preliminary scan was made of a settled $5 \mathrm{ml}$ sample in order to determine the volume to be used for the analyses. For the qualitative analysis at least $5 \mathrm{ml}$ of the sample were analyzed. As a high number of algal cells were present, $1 \mathrm{ml}$ was loaded into a sedimentation chamber of appropriate volume for quantitative analysis. The chamber was topped with a round glass top plate and algae were allowed to settle onto the base of the settling chamber. The 
208 method consists of two parts - analysis of non-diatom phytoplankton ("soft algae") and analysis

209 of diatoms. For the non-diatom phytoplankton analysis, algal cells were enumerated in a settling

210 chamber using an inverted microscope at 400x magnification. Only living forms (i.e. chloroplast

211 containing cells) were counted. At this magnification diatoms are enumerated as a group. For

212 diatom analyses, the samples were pretreated with strong oxidants, cleaned and embedded on

213 glass slides in Naphrax. Actual identification and enumeration of diatoms was done under oil

214 immersion (1000x) and for the quantitative analyses a minimum of 500 frustules was counted (2

215 frustules $=1$ diatom cell) per sample (slide). For the quantitative analyses a minimum of 30

216 microscopic fields is required, including no less than 300 cells. If 300 cells were not observed

217 within the 30 microscopic fields, enumeration was continued until at least 300 were counted. The

218 area counted was recorded to calculate cell number per volume. Algal taxa were identified to the

219 lowest taxonomic rank possible. The taxonomical identification was done using standard

220 literature for species determination (Hindák et al. 1978; Krammer \& Lange-Bertalot 1986;

221 Krammer \& Lange-Bertalot 1988; Krammer \& Lange-Bertalot 1991a; Krammer \& Lange-

222 Bertalot 1991b). Species names were checked at the algae base database (algaeBase 2015).

223 Quantitative assessment was conducted according to Utermöhl (Utermöhl 1958). The density is

224 presented as cell number $\mathrm{L}^{-1}$.

225 Water temperature and water oxygen concentration were measured using an Oxymeter

226 (WTW Oxi 90, WTW GmbH, Weilheim, Bavaria, Germany) and pH was measured using a pH-

227 Meter (WTW pH-95, WTW GmbH, Weilheim, Bavaria, Germany). Solved oxygen content, pH-

228 value and temperature of the water in the tubs was first measured on April 14, shortly before

229 introducing the eggs. Henceforth measurements were performed every third day until May 8. A

230 data logger measuring temperature every 15 minutes was placed in the middle section of each 
231 climate chamber at the start of the experiment. The mean temperature during the experiment was

$23214.4^{\circ} \mathrm{C}$ vs. $18.3^{\circ} \mathrm{C}$ for the $15^{\circ} \mathrm{C}$ vs. $20^{\circ} \mathrm{C}$ treatment, respectively.

233 Water samples $(500 \mathrm{ml})$ of each tub were taken at the start and end of the experiment and

234 immediately stored in a freezer at $-18^{\circ} \mathrm{C}$ before they were analysed for glyphosate and its main

235 metabolite aminomethylphosphonic acid (AMPA) in the laboratories of the BOKU Department

236 of Forest and Soil Sciences using a HPLC-MS/MS method (Popp et al. 2008; Todorovic et al.

237 2013).

238

\section{Statistical Analyses}

240 All statistical analyses were carried out using the open-access software R (version 3.2.1, The R

241 Foundation for Statistical Computing, http://www.r-project.org); $\alpha$ was set at 0.05. Shapiro-

242 Wilks tests and QQ-plots were used to check normality of data. Percentage mortality was arcsin-

243 transformed prior to analysis. To examine whether herbicide concentrations and temperature

244 affected toad larvae morphology, analyses of covariance (ANCOVA) with $\mathrm{pH}$, measured water

245 temperature and oxygen levels as co-variables were conducted. Effects of herbicide and

246 temperature on $\mathrm{pH}$ and dissolved oxygen were tested using a two-way ANOVA. To analyze

247 effects of herbicide, temperature, $\mathrm{pH}$ and dissolved oxygen on algae density and diversity a

248 different ANCOVA model was used as samples were only taken at one point of time. To assess

249 the effects of algae density and diversity on body length, body width, tail length and body length

250 to body width ratio of tadpoles a one-way ANCOVA was conducted. When significant effects

251 were given by the ANCOVA $(\mathrm{P}<0.05)$ a Tukey HSD test was conducted for mean comparisons

252 of herbicide and temperature levels. Water $\mathrm{pH}$ and oxygen concentrations were used as

253 covariates in all ANCOVA models. Correlations were tested using Pearson's test. Values in the

254 text are means \pm standard deviation. 


\section{Results}

258 Herbicide contamination significantly affected tadpole tail length (tl) at $15^{\circ} \mathrm{C}$ but not at $20^{\circ} \mathrm{C}$, 259 occurrence of tail deformations only at $15^{\circ} \mathrm{C}$ and algae diversity (Shannon- and evenness-index) 260 mainly at $20^{\circ} \mathrm{C}$ (Figure 2, Figure 3, Table 1 ). Herbicide concentrations neither affected larval 261 development, body length (bl), body width (bw), body condition (bc), mortality of tadpoles or 262 algae density (Figure 2, Figure 3, Table 1).

263 Temperature significantly affected larval growth parameters (bl, bw, tl and bc), larval 264 development (Gosner stage) and occurrence of tail deformations of tadpoles as well as algae 265 diversity (Shannon- and evenness-index); however it did not affect tadpole mortality or algae 266 density (Figure 2, Figure 3, Table 1). Algal communities contained between 25 to 43 species, 267 with the highest species number in the $15^{\circ} \mathrm{C}$ treatment (Figure 3). Diatom algae dominated in 268 species number and abundance in all mesocosms. 
A

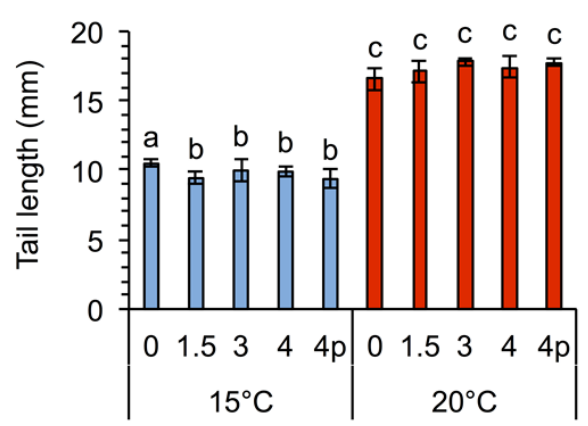

C

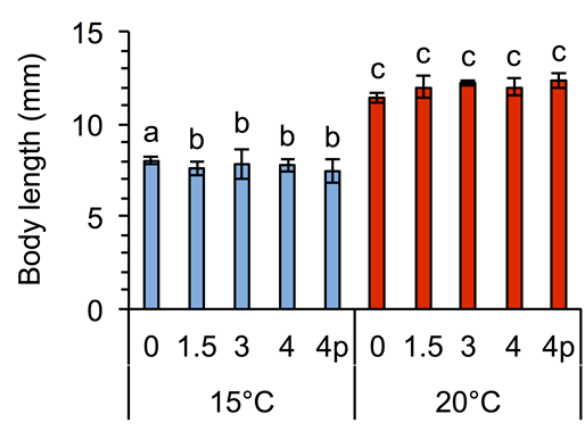

$\mathbf{E}$

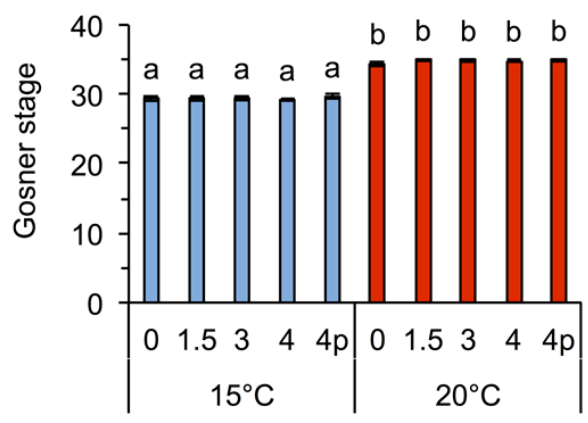

B

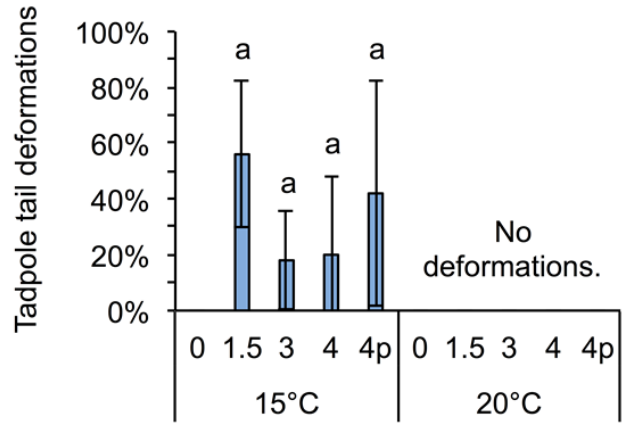

D

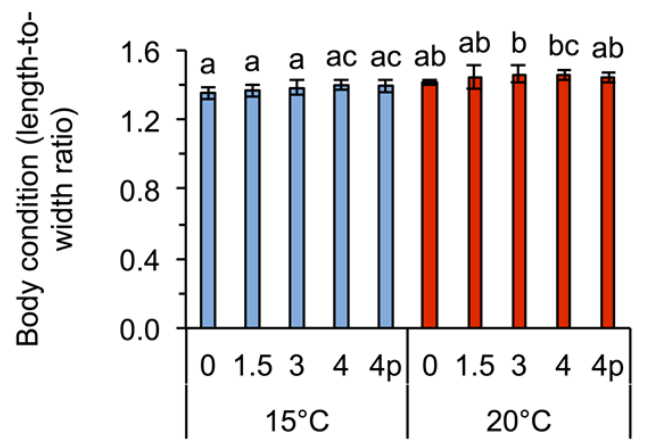

$\mathbf{F}$

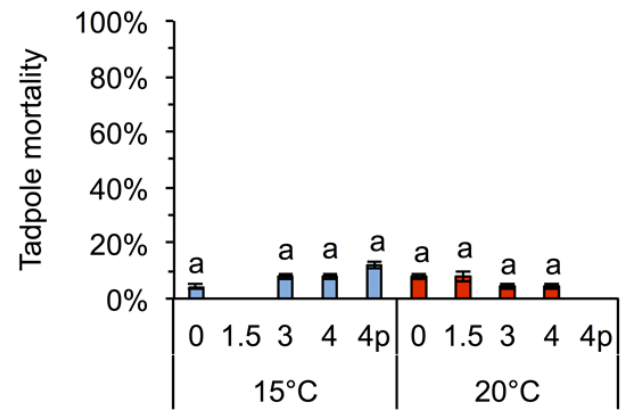

Treatment (mg a.e. $\mathrm{L}^{-1}$ )

271 Figure 2: Tail length (A), tail deformation (B), body length (C), body condition (D), development $(\mathrm{E})$ and mortality $(\mathrm{F})$ of Common toad tadpoles in response to different herbicide treatments $\left(\mathrm{mg}\right.$ a.e. $\left.\mathrm{L}^{-1}\right)$ at $15^{\circ} \mathrm{C}$ or $20^{\circ} \mathrm{C}$, measured 24 days after experiment start. Mean $\pm \mathrm{SD}, \mathrm{n}$ $=5$. Means with different letters are significantly different (Tukey HSD, $\mathrm{p}<0.05$ ). 
A

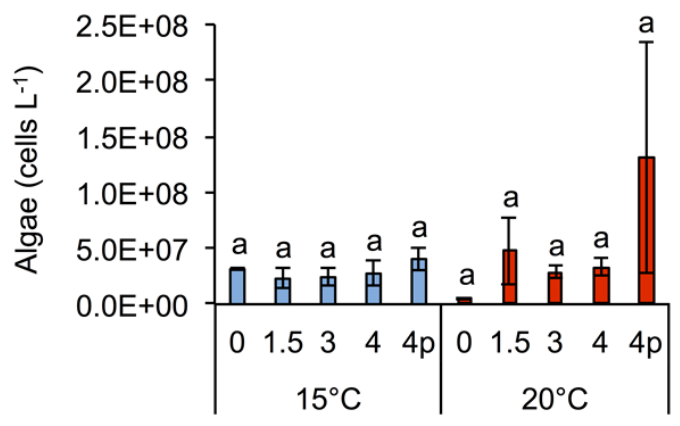

C

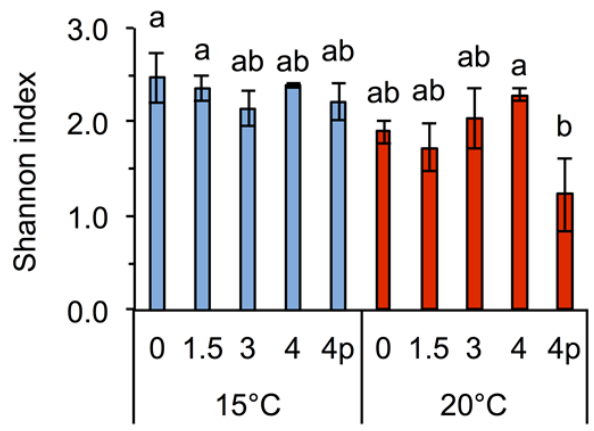

B

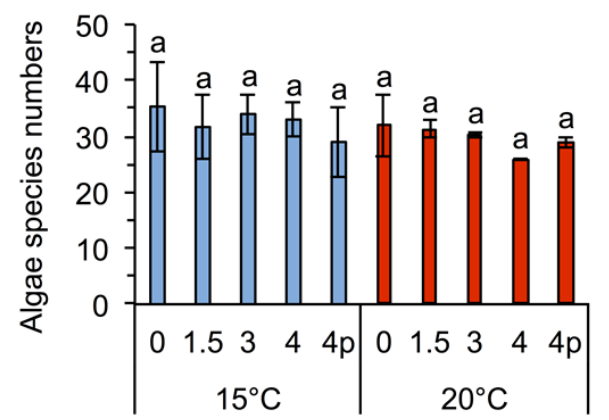

D

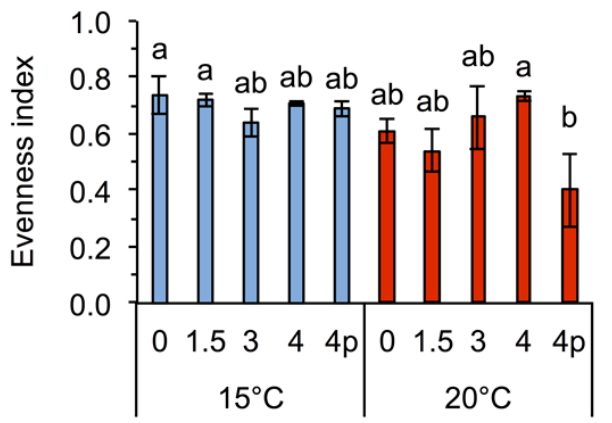

Treatment (mg a.e. $\left.\mathrm{L}^{-1}\right)$

Figure 3: Algae abundance (A), number of species (B) and diversity depicted using Shannon- (C) and evenness-index (D) in response to different herbicide treatments $\left(\mathrm{mg} \mathrm{a.e.} \mathrm{L}^{-1}\right)$ at $15^{\circ} \mathrm{C}$ or $20^{\circ} \mathrm{C}$. Mean $\pm \mathrm{SD}, 24$ days after experiment start, $\mathrm{n}=3$. Means with different letters are significantly different (Tukey HSD, $\mathrm{p}<0.05$ ).

tadpole mortality and occurrence of tail deformations, as well as evenness of algal communities (Figure 2, Figure 3, Table 1). This significant herbicide $\mathrm{x}$ temperature interaction led to the lowest tl $(9.36 \pm 0.64 \mathrm{~mm})$ in the $4 \mathrm{mg}$ a.e. $\mathrm{L}^{-1}$ pulse treatment at $15^{\circ} \mathrm{C}$ and the longest tails $(17.79 \pm 0.31 \mathrm{~mm})$ at $3 \mathrm{mg}$ a.e. $\mathrm{L}^{-1}$ under $20^{\circ} \mathrm{C}$ (Figure $\left.2 \mathrm{~A}\right)$. At $15^{\circ} \mathrm{C}$ tadpoles in tubs contaminated with the herbicide had averaged across herbicide concentrations $7.8 \%$ shorter tails 
291

292

293

294

295

296

297

298

299

300

301

302

303

304

305

306

307

308

309

compared to the control treatment (Figure 2A).

Table 1: ANCOVA results for the effects of herbicide concentrations $\left(0,1.5,3,4,4 \mathrm{p} \mathrm{mg}\right.$ a.e. $\left.\mathrm{L}^{-1}\right)$ and temperature $\left(15^{\circ} \mathrm{C}\right.$ vs. $\left.20^{\circ} \mathrm{C}\right)$ on growth stages, body length (bl), body width (bw), tail length, body condition (bl/bw), mortality and occurrence of tail deformations of Common toad larvae and diversity of associated algal communities.

\begin{tabular}{|c|c|c|c|c|c|c|}
\hline \multirow{2}{*}{ Variable } & \multicolumn{2}{|c|}{ Herbicide conc. } & \multicolumn{2}{|c|}{ Temperature } & \multicolumn{2}{|c|}{ Herbicide $\mathrm{x}$ Temp. } \\
\hline & $\bar{F}$ & $\mathrm{P}$ & $\mathrm{F}$ & $\mathrm{P}$ & $\bar{F}$ & $\mathrm{P}$ \\
\hline \multicolumn{7}{|l|}{ Tadpoles } \\
\hline Growth stages (Gosner) & 0.642 & 0.633 & 150.521 & $<0.001$ & 0.079 & 0.989 \\
\hline Body length (mm) & 1.200 & 0.317 & 837.846 & $<0.001$ & 4.369 & 0.003 \\
\hline Body width (mm) & 0.882 & 0.478 & 584.778 & $<0.001$ & 2.893 & $\mathbf{0 . 0 2 7}$ \\
\hline Tail length (mm) & 4.113 & 0.004 & 891.085 & $<0.001$ & 4.851 & 0.001 \\
\hline Body condition (bl/bw) & 1.413 & 0.236 & 17.040 & $<0.001$ & 2.303 & 0.065 \\
\hline Mortality (\%) & 0.401 & 0.807 & 0.760 & 0.386 & 2.821 & $\mathbf{0 . 0 3 0}$ \\
\hline Tail deformation (\%) & 2.792 & 0.040 & 5.236 & 0.028 & 3.077 & $\mathbf{0 . 0 2 7}$ \\
\hline \multicolumn{7}{|l|}{ Algae } \\
\hline Algal density (cells L $\mathrm{L}^{-1}$ ) & 2.408 & 0.090 & 4.144 & 0.058 & 1.632 & 0.212 \\
\hline Algal diversity (Shannon) & 5.022 & 0.007 & 9.888 & 0.006 & 2.761 & 0.062 \\
\hline Algal diversity (Evenness) & 4.810 & 0.009 & 9.562 & 0.007 & 3.756 & 0.023 \\
\hline
\end{tabular}

Twenty four days after experiment start, tadpoles of the $15^{\circ} \mathrm{C}$ chamber were on average in Gosner stage (Gs) 29, whereas tadpoles at $20^{\circ} \mathrm{C}$ were in Gs 35 (Figure 2E). The body condition was highly significantly affected by temperature, being reduced by $4.2 \%$ at $15^{\circ} \mathrm{C}$ compared to $20^{\circ} \mathrm{C}$, on average across herbicide concentrations (Figure 2D, Table 1). The highest body condition $(1.46 \pm 0.05)$ was found at $3 \mathrm{mg}$ a.e. $\mathrm{L}^{-1}$ under $20^{\circ} \mathrm{C}$, the lowest bl-to-bw ratio $(1.36 \pm 0.04)$ at $0 \mathrm{mg}$ a.e. $\mathrm{L}^{-1}$ under $15^{\circ} \mathrm{C}$. Tadpole bl and bw also differed significantly under different temperature regimes. Body length at $15^{\circ} \mathrm{C}$ was lower by $35.4 \%$ on average compared to $20^{\circ} \mathrm{C}$; whereas bw at $15^{\circ} \mathrm{C}$ was lower by $32.4 \%$ on average compared to $20^{\circ} \mathrm{C}$ (Figure $2 \mathrm{C}$ ). At $15^{\circ} \mathrm{C}$ bl at $0 \mathrm{mg}$ a.e. $\mathrm{L}^{-1}(8.0 \pm 0.18 \mathrm{~mm})$ was significantly higher compared to the other herbicide treatments $(7.67 \pm 0.55 \mathrm{~mm})$; at $20^{\circ} \mathrm{C}$ average bl $(11.99 \pm 0.39 \mathrm{~mm})$ was unaffected by herbicide concentrations (Figure $2 \mathrm{C}$ ). At $15^{\circ} \mathrm{C}$ bw at $4 \mathrm{p} \mathrm{mg} \mathrm{a.e.} \mathrm{L}^{-1}(5.33 \pm 0.33 \mathrm{~mm})$ was significantly 
310 lower compared to the other herbicide concentrations $(5.67 \pm 0.29 \mathrm{~mm})$; at $20^{\circ} \mathrm{C}$ bw $(8.29 \pm 0.39$

$311 \mathrm{~mm}$ ) was unaffected by herbicide concentrations.

312 At the end of the experiment on average $34.0 \pm 14.8 \%$ of the tadpoles at $15^{\circ} \mathrm{C}$ showed

313 deformed tails, while none at $20^{\circ} \mathrm{C}$ had deformed tails (Figure 2B). Most deformed tadpoles

$314(56.0 \pm 26.0 \%)$ were found at $1.5 \mathrm{mg}$ a.e. $\mathrm{L}^{-1}$, however, no relation to herbicide concentration

315 was found. No deformed tadpoles were found in the control group without herbicide addition.

316 Whenever deformations occurred the tip of their tails was crooked in one direction (Figure 1C).

317 Mortality was unaffected by herbicide treatment or temperature, but significantly affected

318 by their interaction: on average, $6.4 \pm 0.8 \%$ of larvae died at $15^{\circ} \mathrm{C}$ vs. $5.6 \pm 0.9 \%$ at $20^{\circ} \mathrm{C}$ (Figure

$3192 \mathrm{~F}$, Table 1$)$. The highest mortality rate under $15^{\circ} \mathrm{C}$ was found at $4 \mathrm{p} \mathrm{mg}$ a.e. $\mathrm{L}^{-1}(12.0 \pm 1.1 \%$

320 mortality), whereas under $20^{\circ} \mathrm{C}$ it was found at $0 \mathrm{mg}$ a.e. $\mathrm{L}^{-1}(8.0 \pm 1.1 \%$ mortality $)$; mortality of

321 control at $15^{\circ} \mathrm{C}$ was $4.0 \pm 0.9 \%$. No larvae died at $1.5 \mathrm{mg}$ a.e. $\mathrm{L}^{-1}$ under $15^{\circ} \mathrm{C}$ and at $4 \mathrm{p} \mathrm{mg}$ a.e.

$322 \mathrm{~L}^{-1}$ under $20^{\circ} \mathrm{C}$ (Figure $\left.2 \mathrm{~F}\right)$.

323 Algal species of 4 different families were observed in the experiment, namely:

324 Chlorophyceae (six spp.), Trebouxiophyceae (two spp.), Xanthophyceae (one spp.) and

325 Bacillariophyceae (34 spp.). Algae Shannon diversity index under $15^{\circ} \mathrm{C}$ was across treatments

$32620.7 \%$ higher than at $20^{\circ} \mathrm{C}$ (Figure $3 \mathrm{C}$ ). At $15^{\circ} \mathrm{C}$ the highest Shannon index was found at $0 \mathrm{mg}$

327 a.e. $\mathrm{L}^{-1}(2.48 \pm 0.27)$, whereas under $20^{\circ} \mathrm{C}$ the highest Shannon index was observed at $4 \mathrm{mg}$ a.e.

$328 \mathrm{~L}^{-1}(2.29 \pm 0.06$; Figure 2$)$. The lowest Shannon index was seen at $3 \mathrm{mg}$ a.e. $\mathrm{L}^{-1}(2.14 \pm 0.18)$

329 under $15^{\circ} \mathrm{C}$ and at $4 \mathrm{p} \mathrm{mg}$ a.e. $\mathrm{L}^{-1}(1.23 \pm 0.39)$ under $20^{\circ} \mathrm{C}$ (Figure $3 \mathrm{C}$ ). Algal density was

330 unaffected by herbicide concentrations or temperature (Table 1). Averaged across concentrations

331 we observed 33 species and $2.9 \mathrm{E}+07 \pm 7.8 \mathrm{E}+06$ algae cells $\mathrm{L}^{-1}$ at $15^{\circ} \mathrm{C}$ vs. 30 species and

$3324.9 \mathrm{E}+07 \pm 3.0 \mathrm{E}+07$ algae cells $\mathrm{L}^{-1}$ at $20^{\circ} \mathrm{C}$ (Figure $3 \mathrm{~A}$ and $\left.\mathrm{B}\right)$. 
Herbicide concentrations affected water $\mathrm{pH}$ and water oxygen concentrations,

334

temperature treatment reduced water oxygen concentration (data provided in supplement S1). At $15^{\circ} \mathrm{C}$, water $\mathrm{pH}$ in the control $(8.34 \pm 0.13)$ was significantly lower than at treatments with herbicide addition $(8.64 \pm 0.48)$, at $20^{\circ} \mathrm{C}$ control showed the lowest value $(8.27 \pm 0.07)$, whereas the pulse treatment had the highest $(8.55 \pm 0.41)$. Across temperatures water oxygen concentration increased with increasing herbicide concentrations. The lower temperature treatment showed higher oxygen values throughout all herbicide concentrations, the highest being $13.58 \pm 4.50 \mathrm{mg} \mathrm{L}^{-1}$ for the $4 \mathrm{mg}$ a.e. $\mathrm{L}^{-1}$ treatment at $15^{\circ} \mathrm{C}$, whereas the control at $20^{\circ} \mathrm{C}$ had the lowest average oxygen value with $9.24 \pm 0.68 \mathrm{mg} \mathrm{L}^{-1}$. No significant effect of herbicide by temperature interaction on water $\mathrm{pH}$ or oxygen was observed. The temperature of the climate chamber had a significant influence on water temperature levels of the tubs, which differed by $3.9^{\circ} \mathrm{C}$. The mean temperature of the $15^{\circ} \mathrm{C}$ and $20^{\circ} \mathrm{C}$ treatment was $14.4 \pm 1.3^{\circ} \mathrm{C}$ and $18.3 \pm$ $1.3^{\circ} \mathrm{C}$, respectively. Tadpole bw and tl was significantly affected by water oxygen concentration, however not affected by water $\mathrm{pH}$ (Table 2). Although bw was significantly affected by water oxygen concentration those parameters were not significantly correlated. Tail deformation was not affected by $\mathrm{pH}$ or dissolved oxygen content (Table 2).

Neither algal density nor algal diversity showed any significant effects on bl, bw, tl and body condition, although algal density had a marginal effect on tadpole bl $(\mathrm{F}=4.096, \mathrm{P}=0.060)$.

Results of glyphosate and AMPA analyses confirmed the indented concentrations at the start of the experiment: $<5.0,1557.5 \pm 33.6,3002.0 \pm 6.3$, and $4050.7 \pm 300.7 \mu$ glyphosate $\mathrm{L}^{-1}$ and generally $<2.5 \mu \mathrm{g}$ AMPA $\mathrm{L}^{-1}$ for the $0,1.5,3,4 \mathrm{mg}$ L-1 one time herbicide application,

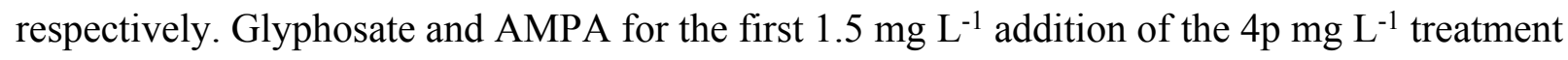
was with $1764.3 \pm 61.8 \mu \mathrm{g}$ glyphosate $\mathrm{L}^{-1}$ higher than intended. At the end of the experiment 
356 measured concentrations across temperature treatments were: $<5.0,1491.4 \pm 148.6,2923.6 \pm$

$357124.8,3979.6 \pm 193.7,6568.3 \pm 1490.3 \mu \mathrm{g}$ glyphosate $\mathrm{L}^{-1}$ and $<2.5,34.6 \pm 13.1,66.0 \pm 35.6$,

$358130.7 \pm 16.2,201.4 \pm 29.8 \mu \mathrm{g} \mathrm{AMPA} \mathrm{L}^{-1}$, for the $0,1.5,3,4 \mathrm{mg} \mathrm{L}^{-1}$ one time herbicide and $4 \mathrm{mg}$

$359 \mathrm{~L}^{-1}$ pulse treatment, respectively.

360

361 Table 2: ANCOVA results for the effects of water $\mathrm{pH}$ and oxygen concentration

362 and time on development, body length, body width, tail length, body condition,

363 mortality and tail deformation of Bufo bufo tadpoles and diversity of associated

364 algae communities.

365

366

367

\section{Tadpoles}

368

Body length (mm)

Body width (mm)

369

Tail length (mm)

Body condition (bl/bw)

370

Mortality (\%)

Tail deformation (\%)

371

Algae

Algal density (cells L-1)

372

Algal diversity (Shannon)

\begin{tabular}{cccc}
\multicolumn{2}{c}{ Water $\mathrm{pH}$} & \multicolumn{2}{l}{ Water oxygen } \\
\hline $\mathrm{F}$ & $\mathrm{P}$ & $\mathrm{F}$ & $\mathrm{P}$ \\
\hline
\end{tabular}

Algal diversity (Evenness)

373

374

\section{Discussion}

376 Our study showed for the first time for Common toads that potential contaminations of spawning

377 ponds with the glyphosate-based herbicide Roundup PowerFlex can reduce the tail growth of

378 toad larvae, lead to tail deformations and reduce the diversity of associated algal communities.

379 Increased water temperature accelerated tadpole development and growth and reduced algal

380 diversity. Moreover, significant interactions between herbicide contamination and temperature

381 affected most morphological parameters (body length, body width, tail length, body condition, 
382 mortality, tail deformation) and algal diversity (evenness-index), suggesting that the herbicide

383 effects are temperature-specific. However, we found no clear indications of a relation between

384 herbicide concentration and tadpole growth parameters or algae diversity or density. However,

385 the presence of glyphosate was decisive for an effect, suggesting that the lowest observed effect

386 concentration (LOEC) was $1.5 \mathrm{mg}$ a.e. glyphosate $\mathrm{L}^{-1}$ water.

387 Overall, our findings for a European amphibian species corroborate former studies

388 showing effects of different Roundup formulations on the growth of mainly North-American

389 amphibian species (Edge et al. 2014; Howe et al. 2004; Lanctôt et al. 2014; Navarro-Martín et al.

390 2014; Relyea 2004; Relyea 2012; Wojtaszek et al. 2004). Our results of 4.2\% decrease in tail

391 length of $B$. bufo tadpoles in tubs containing Roundup PowerFlex $\left(15^{\circ} \mathrm{C}\right)$ compared to the control

392 is in line with findings of a previous study where we tested effects of Roundup LB Plus on $B$.

393 bufo development (Baier et al. 2016). However, the current findings are in contrast to findings of

394 elongated tails of Rana sylvaticus treated with $2.9 \mathrm{mg}$ a.e. L-1 VisionMax (Navarro-Martín et al.

395 2014). In any case it appeared that these glyphosate-based herbicides interfere with molecular

396 signaling processes or growth factors influencing tail growth. Clearly, detailed studies are needed

397 to investigate the underlying mechanisms. Another explanation for a reduced tadpole growth

398 after herbicide addition could be an herbicide-induced decrease of algae diversity that are an

399 important food source for tadpoles (Wojtaszek et al. 2004). Also in our current experiment algae

400 were the preferred food for tadpoles although they were offered ad libitum ground fish food. Our

401 finding that herbicide concentrations affected tadpole growth only at $15^{\circ} \mathrm{C}$ but not at $20^{\circ} \mathrm{C}$

402 suggests that increasing temperature did not significantly enhance the toxicity of the tested

403 herbicide. This observation may also indicate heat hardening in the $20^{\circ} \mathrm{C}$ groups, perhaps caused

404 by an induction of chaperones and following stabilization of developmental processes (Díaz- 
405 Villanueva et al. 2015). Overall, our findings indicate that temperature stress and herbicide stress

406 do not necessarily point in the same direction (Baier et al. 2016; Rohr et al. 2011). Not much is

407 known on ecological consequences of reduced tail length for tadpoles. However, it has been

408 suggested that shorter tailed tadpoles can escape less easily from predators than longer tailed

409 ones (Hoff \& Wassersug 2000; Wilbur \& Semlitsch 1990). Also, tadpole tails are important

410 energy and calcium reservoirs for metamorphosis eventually resulting in smaller toads (Vitt \&

411 Caldwell 2013).

412 As expected, and in accordance with other studies (Derakhshan \& Nokhbatolfoghahai

413 2015; Sanuy et al. 2008), we found that tadpoles at $20^{\circ} \mathrm{C}$ developed and grew much faster than at

$41415^{\circ} \mathrm{C}$, with tail length being 1.6 , body length 1.4 and body width 1.4 times higher on average.

415 Higher temperature also accelerated tadpole development with tadpoles at $20^{\circ} \mathrm{C}$ reaching Gs 35 ,

416 whereas individuals at $15^{\circ} \mathrm{C}$ reached on average Gs 29 until the experiment was terminated; body

417 condition (i.e. body length to body width ratio) was slightly increased by $5 \%$ at higher

418 temperatures. Temperature also had a significant effect on the occurrence of deformed tails, as

419 they were only observed on herbicide treated specimens at $15^{\circ} \mathrm{C}$ but absent at $20^{\circ} \mathrm{C}$. Although

420 climate change models predict higher temperatures during breeding periods (Laloe et al. 2014),

421 breeding and hibernation phenologies of ectotherms might shift to earlier dates during warmer

422 springs for compensating the warmer climate (Benard 2015; Gao et al. 2015; Klaus \& Lougheed

423 2013). In some cases, the phenological shifts following warmer springs and winters even resulted

424 in lower temperatures for the developing tadpoles (Benard 2015). Overall there is still a great

425 lack of data regarding seasonal variations in the water temperature of aquatic bodies used as

426 spawning bonds and to what extent global climate change might affect these. 
428 effects between herbicide and temperature on various parameters regarding tadpoles and algae.

429 To our knowledge it is the first time that such herbicide-temperature interactions for a

430 glyphosate-based herbicide was studied on European toad species and their associated algae. In

431 the herbicide treated tubs at $15^{\circ} \mathrm{C} 34 \%$ of all tadpoles had deformed tails, whereas no deformed

432 tails occurred in the herbicide-free control at $15^{\circ} \mathrm{C}$ or in all herbicide concentrations at $20^{\circ} \mathrm{C}$.

433 Generally, deformation rates $>5 \%$ are considered unnatural and are therefore implemented

434 amphibian monitoring guidelines (Wagner et al. 2014). However, in our experiment tail

435 deformations were not related to herbicide concentrations; to what extent other principles than a

436 dose-response relationship might be effective would need further studies perhaps by also using a

437 greater sample size (Vandenberg et al. 2012). Substantial tail deformations by 50-90\% due to

438 glyphosate-based herbicides have also been found for the tropical frog species Scinax nasicus

439 when exposed to 3.0-7.5 $\mathrm{mg} \mathrm{L}^{-1}$ of Glyfos (Lajmanovich et al. 2003). Also herbicides containing

440 other active ingredients than glyphosate, e.g. isoproturon, have also been reported causing

441 deformations in larvae of Bombina variegata and Rana arvalis at rather low concentrations (0.1-

$442100 \mu \mathrm{g} \mathrm{L}^{-1}$ ) (Greulich 2004). Interestingly, we did not observe tail deformations on tadpole

443 larvae in a previous experiment testing non-target effects of Roundup LB Plus on B. bufo (Baier

444 et al. 2016). This putative discrepancy of effects might be due to the different active ingredients

445 of the tested herbicide products, isopropylamin salt in Roundup LB Plus and potassium salt in

446 Roundup PowerFlex which have been shown to evoke different non-target effects (Cuhra et al.

447 2016) or be the result of different, not-declared adjuvants in the products (Cox \& Surgan 2006;

448 Cuhra et al. 2013; Mullin et al. 2015; Relyea 2005b). 

decrease of body length, body width and tail length by $2-10 \%$ at $15^{\circ} \mathrm{C}$, but the same parameters

451

452 seemed to be (not significantly) increased by $2-8 \%$ at $20^{\circ} \mathrm{C}$ for tadpoles in herbicide treated tubs compared to non-treated tubs. Overall, very little is known about combined effects of pesticides and temperature on aquatic organisms, especially amphibians (Holmstrup et al. 2010; Rohr et al. 2011; Wagner \& Lötters 2013), as most studies investigated herbicide effects at one temperature level only. A study using Roundup Original MAX found effects on tail depth and body depth but not on the body length of Rana pipiens and $R$. sylvaticus tadpoles at $12^{\circ} \mathrm{C}$ (Relyea 2012). Similar to our findings snout-vent length of Rana pipiens larvae decreased when treated with 0.6 and 1.8 mg a.e. $\mathrm{L}^{-1}$ Roundup Original and Roundup Transorb at $20^{\circ} \mathrm{C}$ (Howe et al. 2004). In contrast with our study, growth rates of $R$. clamitans tadpoles treated with $1.43 \mathrm{mg}$ a.e. $\mathrm{L}^{-1}$ Vision herbicide at $20^{\circ} \mathrm{C}$ increased ( $\mathrm{Li}$ et al. 2013). Again, an explanation for these contrasting findings could be that these glyhosate-based herbicides usually differ considerably in the formulation of their active ingredients (Cuhra et al. 2016) their not-declared adjuvants that have been shown to be as detrimental to non-target species as the active ingredient (Mann \& Bidwell 2001; Relyea 2005a; Wagner et al. 2013). To what extent spawning ponds used by amphibians are contaminated with glyphosate-based herbicides is very much dependent on regional circumstances, e.g. how careful herbicide application was conducted following regulations and distances to water bodies. Generally, most studies reporting glyphosate concentrations of surface waters considered larger lakes or streams, while many amphibians are using small, shallow and non-flowing water bodies for spawning. Nevertheless, reported glyphosate concentrations found in surface waters shortly after application scored between 0.27 - $3.10 \mathrm{mg}$ a.e. $\mathrm{L}^{-1}$ (Wagner et al. 2013). 
Algae diversity (Shannon- and evenness-index) in our experiment was significantly

473 reduced by herbicides and increased temperatures, whereas herbicide effects were more

474 pronounced at higher temperature than at lower temperature (herbicide $\mathrm{x}$ temperature

475 interaction). Reductions of algal cells after herbicides application were lower as expected by a

476 pesticide supposed to kill plants. Possible effects of glyphosate-based herbicide formulations on

477 aquatic algae communities have rarely been investigated and our study appears to be among the

478 few addressing this topic for algae communities. Growth of green algae (Scenedesmus acutus, S.

479 quadricauda) was inhibited by technical grade glyphosate and Ron-do, a glyphosate formulation

480 used in aquatic environments (Saenz et al. 1997). In toxicity tests analyzing the effect of

481 glyphosate based herbicides on single species of diatoms and green algae, stronger negative

482 effects on the diatom species (Skeletonema costatum) were observed (Tsui \& Chu 2003). Other

483 studies found growth of $S$. quadricauda was inhibited when treated with an unspecified

484 glyphosate-based formulation (Wong 2000) or by treating four freshwater phytoplankton species

485 with technical grade glyphosate (Vendrell et al. 2009). Since algae are able to produce

486 mycosporine-like amino acids when stressed and this process can depend on the shikimate

487 pathway (Shick \& Dunlap 2002), it is possible, that glyphosate-based herbicides lead to a

488 decrease of the build up of these amino acids (Shick et al. 1999), probably also increasing the

489 effects of temperature stress on algal communities. As expected in our study, dissolved oxygen

490 level was negatively correlated to water temperature. This means that the colder the water, the

491 higher the oxygen content becomes (Wetzel 2001). Although values of water oxygen

492 concentrations varied broadly across temperature and herbicide treatments, we ruled out a lack of

493 oxygen, as the lowest value measured being $8.2 \mathrm{mg} \mathrm{L}^{-1}$, which is considered to be sufficient for

494 proper development of tadpoles (Ultsch et al. 1999). As a consequence of increased temperature 
495 dissolved oxygen levels decreased, which also affected tadpole growth. Contrary to our study,

496 others found decreasing water $\mathrm{pH}$ levels with increasing Roundup concentrations (Tsui \& Chu

497 2003), however this could also be due to unknown adjuvants in the different formulations used.

498

499 Conclusions

500 Our findings might contribute several additional aspects to the broad discussion on non-target

501 effects of pesticides. First, as extreme temperature events will most likely become more frequent

502 due to human-induced climate change (IPCC 2013), it seems imperative to address non-target

503 effects of pesticides also in a climate-change context (Köhler \& Triebskorn 2013; Rohr \& Palmer

504 2013). The herbicide-temperature interactions in the current and a previous (Baier et al. 2016)

505 experiment suggest that interspecific and intraspecific relationships in aquatic ecosystems will

506 most likely be affected when taxa respond differently to these environmental stressors. Second,

507 chronically sub-lethal effects in the morphology and body deformations as well as changes in

508 algae communities such as observed in the current study and their ecological consequences

509 should attract more attention. Third, our study also suggests that ecotoxicological protocols

510 assessing non-target effects of pesticides conducted under constant temperature levels might

511 underestimate real world conditions, especially for poikilothermic vertebrates.

512

\section{Acknowledgements}

514 We are grateful to Mathias Jedinger for sharing his experience during the experimental phase and

515 to Andreas Kitzler (Agilent Technologies Austria) for giving us extensive technical input and

516 support for glyphosate analyses. The manuscript was improved by incorporating comments and

517 suggestions of three anonymous reviewers. 


\section{Supplemental Information}

520 The raw data was submitted as Data S1.

521

\section{Additional Information and Declarations}

523

524 Competing Interests

525 The authors declare there are no competing interests.

526

527 Author Contributions

528 F.B., E.G. and J.G.Z. conceived and conducted the experiment and analyzed the data; B.S.

529 helped with statistics. T.H., E.B.-K. and I.M. analyzed the algal samples. C.B. provided advice

530 throughout the experiment. All authors wrote on the manuscript.

531

532 Data Availability

533 The following information was supplied regarding data availability:

534 The raw data was submitted as Data S1.

535

536 References

537 AGES. 2015. Available at http://pmg.ages.at (accessed 29.09. 2015).

538 Aldrich A, Junghans M, Aeberli C, Brühl CA, Streissl F, and Schmidt BR. 2016. Amphibians and plant539 protection products: what research and action is needed? Environmental Sciences Europe 28:1-8. $540 \quad 10.1186 / \mathrm{s} 12302-016-0085-6$

541 algaeBase. 2015. Available at http://www.algaebase.org (accessed 02.10. 2015). 
542 Annett R, Habibi HR, and Hontela A. 2014. Impact of glyphosate and glyphosate-based herbicides on the

543 freshwater environment. Journal of Applied Toxicology 34:458-479. 10.1002/jat.2997

544 Arnold N, and Ovenden D. 2002. A field guide to the reptiles and amphibians of Britain and Europe.

545 London: HarperCollins.

546 Baier F, Jedinger M, Gruber E, and Zaller JG. 2016. Temperature-dependence of glyphosate-based 547 herbicide's effects on egg and tadpole growth of Common Toads. Frontiers in Environmental Science 548 4:51. doi: 10.3389/fenvs.2016.00051

549 Bantle J, Dumont J, Finch R, Linder G, and Fort D. 1998. Atlas of abnormalities: A guide for the 550 performance of FETAX. Stillwater, OK, USA: Oklahome State University Press.

551 Battaglin WA, Rice KC, Focazio MJ, Salmons S, and Barry RX. 2009. The occurrence of glyphosate, 552 atrazine, and other pesticides in vernal pools and adjacent streams in Washington, DC, Maryland, Iowa, 553 and Wyoming, 2005-2006. Environmental Monitoring and Assessment 155:281-307. 10.1007/s10661$554 \quad 008-0435-y$

555 Baylis AD. 2000. Why glyphosate is a global herbicide: strengths, weaknesses and prospects. Pest 556 Management Science 56:299-308. 10.1002/(SICI)1526-4998(200004)56:4<299::AID-PS144>3.0.CO;2-K

557 Benard MF. 2015. Warmer winters reduce frog fecundity and shift breeding phenology, which 558 consequently alters larval development and metamorphic timing. Global Change Biology 21:1058-1065.

$55910.1111 / \mathrm{gcb} .12720$

560 Berger G, Graef F, and Pfeffer H. 2013. Glyphosate applications on arable fields considerably coincide 561 with migrating amphibians. Scientific Reports $3 . \quad 10.1038 /$ srep02622

562 http://www.nature.com/srep/2013/130910/srep02622/abs/srep02622.html - supplementary563 information

564 Blaustein AR, Han BA, Relyea RA, Johnson PT, Buck JC, Gervasi SS, and Kats LB. 2011. The 565 complexity of amphibian population declines: understanding the role of cofactors in driving amphibian 566 losses. Annals of the New York Academy of Sciences 1223:108-119. 10.1111/j.1749-6632.2010.05909.x

567 Brühl CA, Pieper S, and Weber B. 2011. Amphibians at risk? Susceptibility of terrestrial amphibian life 568 stages to pesticides. Environmental Toxicology and Chemistry 30:2465-2472. 10.1002/etc.650

569 Brühl CA, Schmidt T, Pieper S, and Alscher A. 2013. Terrestrial pesticide exposure of amphibians: an 570 underestimated cause of global decline? Scientific Reports 3:1135. 10.1038/srep01135

571 Butterwick C, Heaney SI, and Talling JF. 2005. Diversity in the influence of temperature on the growth 572 rates of freshwater algae, and its ecological relevance. Freshwater Biology 50:291-300. 10.1111/j.1365573 2427.2004.01317.x

574 Cauble K, and Wagner RS. 2005. Sublethal effects of the herbicide glyphosate on amphibian 575 metamorphosis and development. Bulletin of Environmental Contamination and Toxicology 75:429-435.

576 Collins JP, and Storfer A. 2003. Global amphibian declines: sorting the hypotheses. Diversity and 577 Distributions 9:89-98. 10.1046/j.1472-4642.2003.00012.x 
578 Cooke AS. 1981. Tadpoles as indicators of harmful levels of pollution in the field. Environmenal 579 Pollution 25:123-133.

580 Cox C, and Surgan M. 2006. Unidentified Inert Ingredients in Pesticides: Implications for Human and 581 Environmental Health. Environmental Health Perspectives 114:1803-1806. 10.1289/ehp.9374

582 Cuhra M, Bøhn T, and Cuhra P. 2016. Glyphosate: too much of a good thing? Frontiers in Environmental 583 Science 4:28. doi: 10.3389/fenvs.2016.00028. 10.3389/fenvs.2016.00028

584 Cuhra M, Traavik T, and Bohn T. 2013. Clone- and age-dependent toxicity of a glyphosate commercial 585 formulation and its active ingredient in Daphnia magna. Ecotoxicology 22:251-262. 10.1007/s10646-012$586 \quad 1021-1$

587 Derakhshan Z, and Nokhbatolfoghahai M. 2015. Thermal tolerance limits and effects of temperature on 588 the growth and development of the green toad, Bufotes viridis. German journal of Herpetology 51:129589136.

590 Díaz-Villanueva JF, Díaz-Molina R, and García-González V. 2015. Protein Folding and Mechanisms of 591 Proteostasis. International Journal of Molecular Science 16:17193-17230. doi:10.3390/ijms160817193

592 Duke SO, and Powles SB. 2008. Glyphosate: a once-in-a-century herbicide. Pest Management Science 593 64:319-325. 10.1002/ps.1518

594 Edge C, Thompson D, Hao C, and Houlahan J. 2014. The response of amphibian larvae to exposure to a 595 glyphosate-based herbicide (Roundup WeatherMax) and nutrient enrichment in an ecosystem experiment.

596 Ecotoxicology and Environmental Safety 109:124-132. 10.1016/j.ecoenv.2014.07.040

597 Folmar LC, Sanders HO, and Julin AM. 1979. Toxicity of the herbicide glyphosate and several of its 598 formulations to fish and aquatic invertebrates. Archives of Environmental Contamination and Toxicology $5998: 269-278$.

600 Franz JE, Mao MK, and Sikorski JA. 1997. Glyphosate: a unique global herbicide. Washington, DC: 601 American Chemical Society.

602 Fryday S, and Thompson H. 2012. Toxicity of pesticides to aquatic and terrestrial life stages of 603 amphibians and occurrence, habitat use and exposure of amphibian species in agricultural environments. 604 In: Agency F, and Environment r, editors. Supporting Publications 2012: EN-343. Sand Hutton, York, 605 UK: European Food Safety Authority. p 348.

606 Fuentes L, Moore LJ, Rodgers JH, Bowerman WW, Yarrow GK, and Chao WY. 2011. Comparative 607 toxicity of two glyphosate formulations (Original formulation of Roundup ${ }^{\circledR}$ and Roundup Weathermax ${ }^{\circledR}$ ) 608 to six North American larval anurans. Environmental Toxicology and Chemistry 30:2756-2761. 609 10.1002/etc.670

610 Gao X, Jin C, Llusia D, and Li Y. 2015. Temperature-induced shifts in hibernation behavior in 611 experimental amphibian populations. Scientific Reports 5:11580. 10.1038/srep11580

612 http://www.nature.com/articles/srep11580 - supplementary-information

613 Giesy JP, Dobson S, and Solomon KR. 2000. Ecotoxicological risk assessment for Roundup® Herbicide. 614 Reviews of Environmental Contamination and Toxicology 167:35-120. 
615 Gosner KL. 1960. A simplified table for staging anuran embryos and larvae with notes on identification.

616 Herpetologica 16:183-190.

617 Greulich K. 2004. Einfluss von Pestiziden auf Laich und Larven von Amphibien am Beispiel eines 618 Herbizides (Isoproturon) und eines Insektizides (Cypermethrin). Studien und Tagungsberichte (Band 49).

619 Potsdam: Landesumweltamt Brandenburg.

620 Hindák F, Cyrus Z, Marvan P, Javornický P, Komárek J, Ettl H, Sládečková A, Popovský J, 621 Punčochářová $\mathrm{M}$, and Lhotský O. 1978. Sladkovodné riasy. Bratislava: Slovenské pedagogické 622 nakladatelstvo:.

623 Hoff Kv, and Wassersug RJ. 2000. Tadpole locomotion: axial movement and tail functions in a largely vertebraeless vertebrate. American Zoologist 40:62-076. 10.1093/icb/40.1.62

625 Holmstrup M, Bindesbøl A-M, Oostingh GJ, Duschl A, Scheil V, Köhler H-R, Loureiro S, Soares 626 AMVM, Ferreira ALG, Kienle C, Gerhardt A, Laskowski R, Kramarz PE, Bayley M, Svendsen C, and 627 Spurgeon DJ. 2010. Interactions between effects of environmental chemicals and natural stressors: A 628 review. Science of the Total Environment 408:3746-3762. 629 http://dx.doi.org/10.1016/j.scitotenv.2009.10.067

630 Howe CM, Berrill M, Pauli BD, Helbing CC, Werry K, and Veldhoen N. 2004. Toxicity of glyphosate631 based pesticides to four North American frog species. Environmental Toxicology and Chemistry 23:19286321938.

633 IPCC. 2013. Climate Change 2013: The physical science basis. Contribution of working group I to the 634 fifth assessment report of the intergovernmental panel on climate change. Cambridge, UK and New York, 635 USA: Cambridge University Press.

636 IUCN. 2004. IUCN red list of threatened species : A global species assessment. Gland, SUI and 637 Cambridge, UK: IUCN.

638 Kattwinkel M, Kühne JV, Foit K, and Lies M. 2011. Climate change, agricultural insecticide exposure, and risk for freshwater communities. Ecological Applications 21:2068-2031.

640 Katzenberger M, Hammond J, Duarte H, Tejedo M, Calabuig C, and Relyea RA. 2014. Swimming with 641 Predators and Pesticides: How Environmental Stressors Affect the Thermal Physiology of Tadpoles. 642 PLOS ONE 9. 10.1371/journal.pone.0098265

643 Klaus SP, and Lougheed SC. 2013. Changes in breeding phenology of eastern Ontario frogs over four 644 decades. Ecology and Evolution 3:835-845. 10.1002/ece3.501

645 Köhler HR, and Triebskorn R. 2013. Wildlife Ecotoxicology of Pesticides: Can We Track Effects to the 646 Population Level and Beyond? Science 341:759-765. 10.1126/science.1237591

647 Krammer K, and Lange-Bertalot H. 1986. Süßwasserflora von Mitteleuropa, Band 2/1: 648 Bacillariophyceae, 1. Teil: Naviculaceae. Stuttgart, New York: Gustav Fischer Verlag.

649 Krammer K, and Lange-Bertalot H. 1988. Süßwasserflora von Mitteleuropa, Band 2/2: 650 Bacillariophyceae, 2. Teil: Bacillariaceae, Epithemiaceae, Surirellaceae. Stuttgart, New York: Gustav 651 Fischer Verlag. 
652 Krammer K, and Lange-Bertalot H. 1991a. Süßwasserflora von Mitteleuropa, Band 2/3:

653 Bacillariophyaceae, 3. Teil: Centrales, Fragilariaceae, Eunotiaceae. Stuttgart, Jena: Gustav Fischer 654 Verlag.

655 Krammer K, and Lange-Bertalot H. 1991b. Süßwasserflora von Mitteleuropa, Band 2/4: 656 Bacillariophyceae, 4. Teil: Achnanthaceae, Kritische Ergänzungen zu Navicula (Lineolata) und 657 Gomphonema, Gesamtliteraturverzeichnis Teil 1-4. Stuttgart, Jena: Gustav Fischer Verlag.

658 Lajmanovich RC, Sandoval MT, and Peltzer PM. 2003. Induction of mortality and malformation in 659 Scinax nasicus tadpoles exposed to glyphosate formulations. Bulletin of Environmental Contamination 660 and Toxicology 70:612-618. 10.1007/s00128-003-0029-x

661 Laloe J-O, Cozens J, Renom B, Taxonera A, and Hays GC. 2014. Effects of rising temperature on the viability of an important sea turtle rookery. Nature Clim Change 4:513-518. 10.1038/nclimate2236 http://www.nature.com/nclimate/journal/v4/n6/abs/nclimate2236.html - supplementary-information

Lanctôt C, Navarro-Martín L, Robertson C, Park B, Jackman P, Pauli BD, and Trudeau VL. 2014. Effects of glyphosate-based herbicides on survival, development, growth and sex ratios of wood frog (Lithobates sylvaticus) tadpoles. II: agriculturally relevant exposures to Roundup WeatherMax ${ }^{\circledR}$ and Vision ${ }^{\circledR}$ under laboratory conditions. Aquatic Toxicology 154:291-303. 10.1016/j.aquatox.2014.05.025

Lenhardt PP, Brühl CA, and Berger G. 2015. Temporal coincidence of amphibian migration and pesticide 669 applications on arable fields in spring. Basic and Applied Ecology 16:54-63. 670 http://dx.doi.org/10.1016/j.baae.2014.10.005

671 Li YM, Cohen JM, and Rohr JR. 2013. Review and synthesis of the effects of climate change on 672 amphibians. Integrative Zoology 8:145-161. 10.1111/1749-4877.12001

673 Mann RM, and Bidwell JR. 1999. The toxicity of glyphosate and several glyphosate formulations to four 674 species of southwestern Australian frogs. Archives of Environmental Contamination and Toxicology 675 36:193-199.

676 Mann RM, and Bidwell JR. 2001. The acute toxicity of agricultural surfactants to the tadpoles of four 677 Australian and, two exotic frogs. Environmental Pollution 114:195-205. 10.1016/s0269-7491(00)00216-5

678 Moore H, Chivers DP, and Ferrari MCO. 2015. Sub-lethal effects of Roundup ${ }^{\mathrm{TM}}$ on tadpole anti-predator 679 responses. Ecotoxicology and Environmental Safety 111:281-285. DOI 10.1016/j.ecoenv.2014.10.014

680 Moore LJ, Fuentes L, Rodgers JH, Bowerman WW, Yarrow GK, Chao WY, and Bridges WC. 2012. 681 Relative toxicity of the components of the original formulation of Roundup ${ }^{\circledR}$ to five North American 682 anurans. Ecotoxicology and Environmental Safety 78:128-133. 10.1016/j.ecoenv.2011.11.025

683 Mullin CA, Chen J, Fine JD, Frazier MT, and Frazier JL. 2015. The formulation makes the honey bee 684 poison. Pesticide Biochemistry and Physiology 120:27-35. 685 http://dx.doi.org/10.1016/j.pestbp.2014.12.026

686 Mullin CA, Fine JD, Reynolds RD, and Frazier MT. 2016. Toxicological risks of agrochemical spray 687 adjuvants: organosilicone surfactants may not be safe. Frontiers in Public Health 4:92. doi: 688 10.3389/fpubh.2016.00092. 10.3389/fpubh.2016.00092 
689 Muñoz LMH, Rojas CMM, and Bautista MHB. 2014. Acute toxicity and sublethal effects of the mixture 690 glyphosate (Roundup ${ }^{\circledR}$ Active) and Cosmo-Flux ${ }^{\circledR} 411 \mathrm{~F}$ to anuran embryos and tadpoles of four 691 Colombian species. Revista de Biologia Tropical 63:223-233. 10.15517/rbt.v63i1.12893

692 Navarro-Martín L, Lanctôt C, Jackman P, Park BJ, Doe K, Pauli BD, and Trudeau VL. 2014. Effects of 693 glyphosate-based herbicides on survival, development, growth and sex ratios of wood frogs (Lithobates 694 sylvaticus) tadpoles. I: Chronic laboratory exposures to VisionMax ${ }^{\circledR}$. Aquatic Toxicology 154:278-290. 695 http://dx.doi.org/10.1016/j.aquatox.2014.05.017

696 Noyes PD, McElwee MK, Miller HD, Clark BW, Van Tiem LA, Walcott KC, Erwin KN, and Levin ED. 697 2009. The toxicology of climate change: Environmental contaminants in a warming world. Environment 698 International 35:971-986. http://dx.doi.org/10.1016/j.envint.2009.02.006

699 Peruzzo PJ, Porta AA, and Ronco AE. 2008. Levels of glyphosate in surface waters, sediments and soils 700 associated with direct sowing soybean cultivation in north pampasic region of Argentina. Environmental 701 Pollution 156:61-66. 10.1016/j.envpol.2008.01.015

702 Popp M, Hann S, Mentler A, Fürhacker M, Stingeder G, and Köllensperger G. 2008. Determination of 703 glyphosate and AMPA in surface and waste water using high-performance ion chromatography coupled 704 to inductively coupled plasma dynamic reaction cell mass spectrometry (HPIC-ICP-DRC-MS). Analytical 705 and Bioanalytical Chemistry 391:695-699.

706 Recuero E, Canestrelli D, Voros J, Szabo K, Poyarkov NA, Arntzen JW, Crnobrnja-Isailovic J, Kidov 707 AA, Cogalniceanu D, Caputo FP, Nascetti G, and Martinez-Solano I. 2012. Multilocus species tree 708 analyses resolve the radiation of the widespread Bufo bufo species group (Anura, Bufonidae). Molecular 709 Phylogenetics And Evolution 62:71-86. 10.1016/j.ympev.2011.09.008

710 Relyea RA. 2004. Growth and survival of five amphibian species exposed to combinations of pesticides. 711 Environmental Toxicology and Chemistry 23:1737-1742.

712 Relyea RA. 2005a. The impact of insecticides and herbicides on the biodiversity and productivity of 713 aquatic communities. Ecological Applications 15:618-627. 10.1890/03-5342

714 Relyea RA. 2005b. The letal impact of Roundup on aquatic and terrestrial amphibians. Ecological 715 Applications 15:1118-1124. 10.1890/04-1291

716 Relyea RA. 2011. Amphibians are not ready for Roundup®. In: Elliott JE, Bishop CA, and Morrissey 717 CA, eds. Wildlife ecotoxicology: forensic approaches. New York: Springer, 466.

718 Relyea RA. 2012. New effects of Roundup on amphibians: Predators reduce herbicide mortality; 719 herbicides induce antipredator morphology. Ecological Applications 22:634-647.

720 Rohr J, Madison D, and Sullivan A. 2003. On temporal variation and conflicting selection pressures: a 721 test of theory using newts. Ecology 84:1816-1826.

722 Rohr JR, and Palmer BD. 2013. Climate Change, Multiple Stressors, and the Decline of Ectotherms. 723 Conservation Biology 27:741-751. 10.1111/cobi.12086

724 Rohr JR, Sesterhenn TM, and Stieha C. 2011. Will climate change reduce the effects of a pesticide on 725 amphibians?: partitioning effects on exposure and susceptibility to contaminants. Global Change Biology 726 17:657-666. 10.1111/j.1365-2486.2010.02301.x 
727

728

729

730

731

732

733

734

735

736

737

738

739

740

741

742

743

744

745

746

747

748

749

750

751

752

753

754

755

756

757

758

759

760

761

762

763

Saenz ME, Di Marzio WD, Alberdi JL, and del Carmen Tortorelli M. 1997. Effects of technical grade and a commercial formulation of glyphosate on algal population growth. Bulletin of Environmental Contamination and Toxicology 59:638-644.

Sanuy D, Oromí N, and Galofré A. 2008. Effects of temperature on embryonic and larval development and growth in the natterjack toad (Bufo calamita) in a semi-arid zone. Animal Biodiversity and Conservation 31:41-46.

Schabhüttl S, Hingsamer P, Weigelhofer G, Hein T, Weigert A, and Striebel M. 2013. Temperature and species richness effects in phytoplankton communities. Oecologia 171:527-536. 10.1007/s00442-0122419-4

Shick JM, and Dunlap WC. 2002. Mycosporine-Like Amino Acids and Related Gadusols: Biosynthesis, Accumulation, and UV-Protective Functions in Aquatic Organisms. Annual Review of Physiology 64:223262. doi:10.1146/annurev.physiol.64.081501.155802

Shick JM, Romaine-Lioud S, Romaine-Lioud S, Ferrier-Pagès C, and Gattuso JP. 1999. Ultraviolet-B radiation stimulates shikimate pathway-dependent accumulation of mycosporine-like amino acids in the coral Stylophora pistillata despite decreases in its population of symbiotic dinoflagellates. Limnology and Oceanography 44:1667-1682. 10.4319/10.1999.44.7.1667

Struger J, Thompson D, Staznik B, Martin P, McDaniel T, and Marvin C. 2008. Occurrence of glyphosate in surface waters of Southern Ontario. Bulletin of Environmental Contamination and Toxicology 80:378384. 10.1007/s00128-008-9373-1 10.1007/s00128-008-9373-1. Epub 2008 Mar 5.

Todorovic G, Mentler A, Popp M, Hann S, Kollensperger G, Rampazzo N, and Blum W. 2013. Determination of glyphosate and AMPA in three representative agricultural Austrian soils with a HPLCMS/MS method. Soil Sediments and Contamination 22:332-350.

Trumbo J. 2005. An assessment of the hazard of a mixture of the herbicide Rodeo ${ }^{\circledR}$ and the non-ionic surfactant R-11® to aquatic invertebrates and larval amphibians. California Fish and Game 91:38-46.

Tsui MTK, and Chu LM. 2003. Aquatic toxicity of glyphosate-based formulations: comparison between different organisms and the effects of environmental factors. Chemosphere 52:1189-1197. $10.1016 / \mathrm{S} 0045-6535(03) 00306-0$

Ultsch G, Bradford D, and Freda J. 1999. Physiology: coping with the environment (Chapter 8). In: McDiarmid R, and Altig R, eds. Tadpoles: The biology of anuran larvae. Chicago: University of Chicago Press, 189-214.

Utermöhl H. 1958. Zur Vervollkommnung der quantitativen Phytoplankton-Methodik. Mitteilungen der internationalen Vereinigung für theoretische und angewandte Limnologie 9:1-38.

Vandenberg LN, Colborn T, Hayes TB, Heindel JJ, Jacobs DR, Lee D-H, Shioda T, Soto AM, vom Saal FS, Welshons WV, Zoeller RT, and Myers JP. 2012. Hormones and Endocrine-Disrupting Chemicals: Low-Dose Effects and Nonmonotonic Dose Responses. Endocrine Reviews 33:378-455. 10.1210/er.20111050 
764

765

766

767

768

769

770

771

772

773

774

775

776

777

778

779

780

781

782

783

784

785

786

787

788

789

790

791

792

793

794

Vendrell E, Gómez de Barreda Ferraz D, Sabater C, and Carrasco JM. 2009. Effect of glyphosate on growth of four freshwater species of phytoplankton: A microplate bioassay. Bulletin of Environmental Contamination and Toxicology 82:538-542. 10.1007/s00128-009-9674-z

Vitt LJ, and Caldwell JP. 2013. Herpetology: An Introductory Biology of Amphibians and Reptiles. London, UK: Academic Press.

Wagner N, and Lötters S. 2013. Effects of Water Contamination on Site Selection by Amphibians: Experiences from an Arena Approach With European Frogs and Newts. Archives of Environmental Contamination and Toxicology 65:98-104. 10.1007/s00244-013-9873-9

Wagner N, Reichenbecher W, Teichmann H, Tappeser B, and Lötters S. 2013. Questions concerning the potential impact of glyphosate-based herbicides on amphibians. Environmental Toxicology and Chemistry 32:1688-1700. 10.1002/etc.2268

Wagner N, Züghart W, Mingo V, and Lötters S. 2014. Are deformation rates of anuran developmental stages suitable indicators for environmental pollution? Possibilities and limitations. Ecological Indicators 45:394-401.

Wetzel RG. 2001. Limnology : lake and river ecosystems. San Diego, USA and London, UK: Academic.

Whitehead PG, Wilby RL, Battarbee RW, Kernan M, and Wade AJ. 2009. A review of the potential impacts of climate change on surface water quality. Hydrological Sciences Journal 54:101-123. 10.1623/hysj.54.1.101

Wilbur HM, and Semlitsch RD. 1990. Ecological consequences of tail injury in Rana tadpoles. Copeia 1990:18-24. 10.2307/1445817

Williams BK, and Semlitsch RD. 2010. Larval responses of three Midwestern anurans to chronic, lowdose exposures of four herbicides. Archives of Environmental Contamination and Toxicology 58:819-827. $10.1007 / \mathrm{s} 00244-009-9390-\mathrm{z}$

Wilson BA, Smith VH, deNoyelles F, and Larive CK. 2003. Effects of Three Pharmaceutical and Personal Care Products on Natural Freshwater Algal Assemblages. Environmental Science \& Technology 37:1713-1719. 10.1021/es0259741

Wojtaszek BF, Staznik B, Chartrand DT, Stephenson GR, and Thompson DG. 2004. Effects of Vision® herbicide on mortality, avoidance response, and growth of amphibian larvae in two forest wetlands. Environmental Toxicology and Chemistry 23:832-842. Doi 10.1897/02-281

Wong PK. 2000. Effects of 2,4-D, glyphosate and paraquat on growth, photosynthesis and chlorophyll-a synthesis of Scenedesmus quadricauda Berb 614. Chemosphere 41:177-182. 